\title{
KAJIAN LITERATUR EFEKTIVITAS ELECTRONIC WORD OF MOUTH (E-WOM) DALAM MENINGKATKAN MINAT BELI KONSUMEN DI SOSIAL MEDIA
}

\author{
Yosinta Damayanti \\ Program Studi Manajemen, Fakultas Ekonomi dan Bisnis Islam, Universitas Islam Negeri Sunan Ampel Surabaya \\ Jl. Ahmad Yani No.117, Jemur Wonosari, Kecamatan Wonocolo, Kota Surabaya, Jawa Timur 60237 \\ yosinta.damayanti07@gmail.com
}

\begin{abstract}
Today the development of technology is very fast, especially in the field of marketing. One of the proof is the emergence of Electronic Word of Mouth or e-WOM which is the next development of Word of Mouth or WOM. E-WOM is a support facility of businessmen in providing perceptions of good value for customers on social media. E-WOM used as communication in the marketing field on social media is offered to increase consumer buying interest in the products offered. E-WOM contains shared messages by consumers that related to purchases products, and can be used as a medium for delivering information related to products, both in terms of quality, or in terms of service provided by the seller. A lot of the companies have successfully understood the power of electronic word of mouth (e-WOM) on social media, this can be seen from the proliferation of companies offering their products on social media by using e-WOM to provide good advice from the sale of products. The purpose of this research is to provide scientific development and insight related to the effectiveness of Electronic Word of Mouth (e-WOM) in increasing the purchase interest of consumers. The type of research used is descriptive qualitative with the study literature method. Overall, the results of this literature review can conclude that Electronic Word of Mouth (e-WOM) can increase purchase interest of consumers on social media. The results are supported by several studies that show e-WOM can increase purchase interest of the consumer on social media.
\end{abstract}

Keywords: Consumers, Electronic Word of Mouth(e-WOM), Purchase Interest, Social Media

\section{PENDAHULUAN}

Seiring dengan perkembangan teknologi yang semakin pesat, perkembangan pada bidang komunikasi juga terus berlangsung. Saat ini, komunikasi menjadi lebih mudah dilakukan, terlebih dengan hadirnya internet yang dianggap menjadi media yang efektif dan efisien dalam menunjang proses komunikasi. Kehadiran internet tersebut disambut baik oleh masyarakat, maraknya penggunaan internet dibuktikan dengan perilaku masyarakat yang melibatkan internet pada segala aspek kehidupan. Banyaknya pengguna internet juga menyebabkan perdagangan dengan basis internet (e-commerce) ikut bertumbuh. Pernyataan tersebut didukung oleh hasil riset yang dilakukan oleh Badan Pusat Statistik (BPS) yang menyebutkan bahwa jumlah transaksi pada e-commerce Indonesia di tahun 2018 mencapai 24,82juta transaksi (Statistik E-Commerce, 2019).

Kemudahan akses internet yang diiringi dengan pertumbuhan e-commerce menjadikan banyak masyarakat menggunakan internet sebagai media mencari 
berbagai informasi terkait suatu produk apabila ingin melakukan pembelian. Salah satu tempat yang digunakan untuk mencari informasi produk adalah sosial media. Sosial media menjadi begitu populer karena konsumen dapat memiliki kebebasan dalam mengakses informasi yang dicari. Kemudahan dalam mendapatkan informasi juga menjadikan konsumen lebih cenderung menggunakan sosial media dalam melakukan pembelian. Terdapat berbagai macam sosial media dalam proses marketing, yaitu meliputi instagram, twitter, facebook, youtube dan lain sebagainya. APJII mengeluarkan data survei terkait penggunaan sosial media di tahun 2016 dengan persentase yaitu 54\% untuk Facebook, 15\% untuk Instagram, dan 5,5\% untuk twitter.

Perkembangan internet sangat menguntungkan bagi penjual, terutama dalam bidang pemasaran. Pada mulanya, pemasaran suatu produk hanya dilakukan dengan cara komunikasi face to face, iklan di televisi ataupun melalui koran. Namun dengan hadirnya internet, pemasaran menjadi dapat dilakukan dengan lebih interaktif, salah satu contoh dari produk internet yang dapat membantu proses pemasaran adalah sosial media. Pemasaran dengan sosial media akan menjadi efektif melihat terdapat banyak penggunaan sosial media oleh masyarakat. Penggunaan sosial media yang semakin bertambah membukakan peluang bagi para penjual untuk melakukan penawaran produknya pada konsumen melalui sosial media. Penjual selalu berupaya untuk menjadikan sosial media sebagai media komunikasi dan media pemasaran yaitu dengan menggunakan sosial media sebagai wadah informasi produk yang ditawarkan. Dengan adanya komunikasi tersebut, penjual dan pembeli akan samasama memiliki informasi terkait satu sama lain. Disamping itu, komunikasi yang terjalin antara penjual dan konsumen dalam sosial media tersebut ditujukan untuk memudahkan pengambilan keputusan konsumen terkait pembelian suatu produk, yang selanjutnya dapat diarahkan pada transaksi pembelian.

Sosial media dapat digunakan sebagai strategi komunikasi pemasaran. Hal tersebut terlihat dari beberapa penawaran produk di sosial media yang menggunakan electronic word of mouth (e-WOM) sebagai upaya para pelaku bisnis dalam memberikan persepsi berupa nilai yang baik bagi pelanggan. Penggunaan strategi tersebut bertujuan untuk dapat meningkatkan minat beli konsumen terhadap produk yang ditawarkan. E-WOM dapat berisikan pesan yang dibagikan oleh konsumen terkait pengalaman pembelian produk, serta dapat dijadikan sebagai media penyampaian informasi terkait produk, baik itu dari segi kualitas, ataupun dari segi pelayanan yang dilakukan penjual. Tidak sedikit dari perusahaan yang telah memahami kekuatan electronic word of mouth (e-WOM) di sosial media, hal tersebut terlihat dari menjamurnya perusahaan yang menawarkan produknya di sosial media dengan memanfaatkan $e$-WOM untuk menunjukkan tanggapan baik dari penjualan produknya. Chevalier dan Mayzlin juga berpendapat bahwa minat beli akan suatu produk menjadi semakin tinggi seiring dengan $e$-WOM yang terus dilakukan (Donni Juni Priansa, 2016, p.119). Secara lebih rinci, minat beli konsumen pada suatu produk dapat muncul karena mendapatkan informasi terkait pengalaman penggunaan suatu produk, sedangkan e-WOM akan memberikan gambaran terkait pengalaman 
penggunaan ataupun konsumsi suatu produk tersebut, sehingga konsumen yang belum memiliki pengalaman penggunaan produk tetap dapat memperoleh informasi terkait pengalaman penggunaan produk tersebut. Oleh karena itu, akan sangal penting untuk melakukan kajian terkait efektivitas e-WOM karena campur tangan dari eWOM dalam era modern ini akan sangat memiliki peran baik bagi pihak penjual ataupun konsumen.

Atas dasar latar belakang tersebut, penulis penulis tertarik untuk melakukan kajian literatur yang mengangkat electronic word of mouth (e-WOM) dan kaitannya dengan minat beli konsumen dengan judul "Kajian Literatur Efektivitas Electronic Word of Mouth (e-WOM) dalam Meningkatkan Minat Beli Konsumen di Sosial Media". Kajian literatur ini diharapkan dapat menjadi referensi ataupun rujukan untuk semakin mendorong perkembangan electronic word of mouth (e-WOM) sehingga dapat memberikan pengaruh positif bagi penjual di media online ataupun konsumen.

\section{METODE PENELITIAN}

Penelitian ini menggunakan metode penelitian kualitatif diskriptif dengan metode studi literatur. Penelitian kualitatif merupakan penelitian yang menggunakan latar belakang ilmiah yang bertujuan memperoleh hasil penelitian secara deskriptif atau analisis (Suharsimi Arikunto, 2010, p.3). Sedangkan studi literatur atau kajian literatur (literature research) yang digunakan dalam penenelitian ini bertujuan untuk mengkaji pengetahuan, gagasan, dan temuan yang didapatkan dari literatur dengan orientasi akademik. Selanjutnya, penulis menyusun hasil temuan yang berupa kontribusi teoritis serta metodologisnya tersebut secara sistematis sesuai dengan topik yang telah dipilih oleh penulis (Cooper dan Taylor dalam Mohammad Imam Farisi, 2010). Cara perolehan data pada studi literatur ini dilakukan dengan mengumpulkan data kepustakaan yang dianggap relevan dengan penelitian, yaitu berasal dari informasi kepustakaan yang berupa jurnal, buku, artikel, koran dan lain sebagainya. Data utama dalam studi literatur ini berasal dari 5 jurnal tentang Electronic Word of Mouth (e-WOM) dan kaitannya dalam minat beli konsumen, sehingga output yang dihasilkan berupa pengembangan keilmuan dan wawasan terkait efektivitas Electronic Word of Mouth (e-WOM) dalam meningkatkan minat beli konsumen.

\section{PEMBAHASAN}

Berdasarkan pada pencarian literatur yang dilakukan penulis, maka berikut merupakan beberapa penelitian terdahulu yang berisikan analisa tentang Electronic Word of Mouth (e-WOM) dan kaitannya dalam minat beli konsumen di sosial media, yaitu diantaranya:

1. Penelitian yang berjudul "Analisis Faktor-Faktor Pembentuk Electronic Word-Of-Mouth (eWOM) dan Pengaruhnya Terhadap Minat Beli (Survei 
Pada Followers Akun Instagram @Saboten_Shokudo)”yang ditulis oleh Firman Dwi Cahyono, Andriani Kusumawati, dan Srikandi Kumadji.

Penelitian tersebut dilakukan dengan tujuan untuk memberikan penjelasan faktor-faktor pembentuk Electronic Word of Mouth (eWOM), memberikan penjelasan terkait pengaruh dari faktor-faktor tersebut terhadap minat beli, serta mengetahui faktor manakah yang memiliki pengaruh lebih dominan terhadap minat beli. Sedangkan hasil penelitian tersabut menjelaskan bahwa terdapat lima faktor pembentuk Electronic Word of Mouth (e-WOM), yakni yang pertama adalah platform assistance, kedua expressing positive feelings, ketiga Economic Incentives, keempat helping the company, dan yang kelima adalah concern for others. Sedangkan untuk faktor yang memiliki pengaruh paling dominan terhadap minat beli adalah faktor concern for others. Disamping itu, peneliti juga memberikan saran agar penelitian selanjutnya yang serupa dapat dilakukan dengan menggunakan platform yang berbeda sehingga dapat lebih memberikan wawasan yang lebih luas apabila terdapat perbedaan hasil dari penelitian sebelumnya

2. Penelitian lain yaitu dengan judul "Analisa Electronic Word of Mouth (EWOM) Pada Media Sosial Twitter" yang ditulis oleh Heribertus Yulianton, Felix Andreas Sutanto, dan Kristophorus Hadiono. Tujuan dari dilakukannya penelitian tersebut adalah mengidentifikasi dan menganalisis motif-motif dari e-WOM pada sosial media Twitter, serta untuk mengetahui motif manakah yang paling sering dipilih oleh pengguna sosial media Twitter untuk dilakukan. Sedangkan hasil dari penelitian tersebut berupa data dari dua motif e-WOM yaitu Venting Negative Feelings dan Extraversion atau Positive Self-Enhancement. Kegunaan dari data tersebut adalah sebagai pendukung keputusan pemilihan penyedia jasa internet yang baik bagi pengguna internet

3. Penelitian terdahulu ketiga ditulis oleh Honorata Ratnawati Dwi Putranti, dan Denny Pradana, yang berjudul "Electronic Word of Mouth (E-WOM), Kepuasan Konsumen dan Pengaruh Langsung dan Tak Langsung Terhadap Minat Beli Konsumen (Studi Pada Mahasiswa FEB UNTAG di Semarang)". Penelitian tersebut dilakukan dengan 3 tujuan yaitu untuk mengetahui bagaimana pengaruh dari e-WOM pada sosial media, selanjutnya adalah untuk mengetahui bagaimana pengaruh dari kepuasan konsumen pada sosial media, dan yang terakhir adalah untuk mengetahui bagaimana pengaruh dari e-WOM baik secara langsung ataupun tidak langsung terhadap minat beli konsumen. Sedangkan hasil penelitian ini menyebutkan bahwa berdasarkan pada uji hipotesis, e-WOM dan kepuasan konsumen memiliki pengaruh positif yang signifikan terhadap sosial media. Hasil pengujian juga menunjukkan bahwa kepuasan konsumen memiliki pengaruh yang positif terhadap e-WOM, dan e-WOM memiliki pengaruh baik itu secara langsung ataupun tidak langsung terhadap minat beli konsumen. Peneliti juga menyebutkan bahwa dengan adanya sosial media, maka semakin terbuka peluang adanya media promosi yang efektif dan efisien. Peneliti juga memberikan saran agar para penjual yang menggunakan sosial media dapat 
mengajak lebih banyak penjual lain untuk ikut menggunakan sosial media dalam menjual produknya, hal tersebut dilakukan agar konsumen memiliki lebih banyak pilihan terkait produk yang sedang dicari, sehingga akan meningkatkan minat belinya terhadap produk melalui sosial media.

4. Penelitian selanjutnya berjudul "Analisis Pengaruh Electronic Word of Mouth (E-WOM) Terhadap Minat Beli Konsumen Pada Produk Tas Di Instagram Rgfashion Store" yang ditulis oleh Gevi Tonida Resky. Tujuan penelitian tersebut adalah mengetahui bagaimana pengaruh dari Electronic Word of Mouth (e-WOM) pada minat beli produk tas dalam akun sosial media instagram Rgfashion Store. Hasil penelitian tersebut menyebutkan bahwa terdapat pengaruh positif yang signifikan dari Electronic Word of Mouth (e-WOM) dalam sosial media Instagram pada minat beli, yakni minat beli pada produk tas dalam akun Rgfashion Store. Peneliti juga memberi saran bagi penjual produk, khususnya produk tas pada akun Instagram Rgfashion Store agar penjual dapat berupaya membangun citra positif dari produk yang dijual. Hal tersebut dilakukan agar dapat menambah minat beli konsumen atas produk.

5. Penelitian kelima berjudul "Apakah E-WOM (Electronic Word of Mouth) Bisa Mengalahkan WOM (Word of Mouth) Dalam Mempengaruhi Penjualan Produk Kuliner" yang ditulis oleh Lavenia Hariono. Penelitian tersebut dilakukan dengan harapan agar dapat membantu pemasar yang tengah melakukan tinjauan kritis terkait Electronic Word of Mouth (e-WOM) dan Word of Mouth (WOM) dalam mempengaruhi penjualan produk kuliner. Hasil dari penelitian tersebut menunjukkan bahwa terdapat peran penting dari WOM dalam proses promosi suatu produk, sedangkan e-WOM sendiri merupakan perkembangan bentuk dari WOM yang muncul seiring dengan adanya perkembangan teknologi. Karena perkembangan teknologi pula, eWOM dapat dikatakan lebih unggul dari WOM apabila dikaitkan dengan pengaruhnya pada penjualan produk, hal tersebut disebabkan salah satunya adalah karena e-WOM memiliki jangkauan yang lebih besar dari WOM.

Berdasar pada lima penelitian terdahulu yang relevan tersebut, penulis berupaya melakukan analisa terkait efektivitas Electronic Word of Mouth (e-WOM) dalam meningkatkan minat beli konsumen di sosial media. Analisis tersebut diharapkan dapat menjadi penelitian lanjutan yang berguna untuk melengkapi penelitian terdahulu yang mengkaji hal serupa.

\section{Konsep Dasar dari Pemasaran}

Pemasaran dapat dikatakan sebagai sebuah jiwa dalam menjalankan bisnis. Bagi masyarakat awam, pemasaran hanya diartikan sebagai kegiatan promosi, padahal pemasaran memiliki pengertian yang lebih luas lagi. Definisi dari pemasaran dikemukakan oleh AMA (America Marketing Association) yang menyebutkan bahwa pemasaran merupakan suatu aktivitas dan serangkaian proses yakni creating 
(menciptakan), communicating (berkomunikasi), delivering (menyampaikan), serta pertukaran penawaran yang mengandung nilai untuk pelanggan, klien, mitra, ataupun masyarakat secara umum (Kotler dan Keller 2016, p.27). Kotler dan Keller (2016) juga mengungkapkan bahwa pemasaran merupakan kegiatan yang berkaitan dengan identifikasi, dan pemenuhan kebutuhan dari manusia, dan kebutuhan tersebut dilakukan dengan cara yang menguntungkan (baik itu bagi produsen ataupun konsumen). Definisi lain dari pemasaran dikemukakan oleh Miller dan Layton dalam Fandy Tjiptono (2014, p.13) yang menyatakan bahwa pemasaran merupakan suatu sistem pada total aktivitas bisnis yang dibuat untuk mencapai tujuan organisasi. Sistem total aktivitas bisnis tersebut dapat berupa suatu perencanaan, proses menetapkan harga, mempromosikan, serta mendistribusikan suatu produk baik itu berupa barang ataupun jasa yang dapat memenuhi kebutuhan pasar.

Dari definisi-definisi tersebut, dapat terlihat bahwa pemasaran bukan hanya sebatas mempromosikan suatu produk, namun juga terdiri dari berbagai rangkaian mulai dari perencanaan hingga pendistribusian produk. Bagi sebuah bisnis, pemasaran memegang peran penting dalam keberlangsungannya, hal tersebut disebabkan karena pemasaran merupakan kegiatan utama yang dilakukan dalam proses mencari keuntungan yang selanjutnya akan menjaga kelangsungan perusahaan. Seorang pebisnis atau penjual produk tentunya akan selalu berusaha untuk dapat mengidentifikasi keinginan konsumen, karena hanya dengan mengetahui keinginan konsumen maka penjual akan dapat mengetahui cara pemenuhan keinginan konsumen tersebut yang tentunya dilakukan melalui proses pertukaran yang dapat menguntungkan kedua belah pihak.

Saat ini, kita dihadapkan pada kondisi dimana penggunaan internet telah merambah pada bidang operasi bisnis. Internet telah dijadikan sebagai alat komunikasi pemasaran antara penjual dan konsumennya. Komunikasi dalam pemasaran merupakan suatu sarana yang berguna untuk memberi informasi, memberikan persuasi, serta memberi pengingat terkait produk yang dijual pada konsumen secara langsung ataupun tidak langsung (Kotler dan Keller, 2012, p.498). Komunikasi pemasaran secara umum dilakukan dengan penyampaian informasi terkait produk yang dijual kepada konsumen menggunakan media atau saluran yang tersedia. Dengan adanya perkembangan teknologi yang melahirkan internet, maka penjual cenderung beralih dari komunikasi pemasaran tradisional (menggunakan media tv atau radio) menuju ke komunikasi pemasaran yang menggunakan peran internet. Hal tersebut disebabkan karena internet memiliki jangkauan yang lebih luas, tidak dibatasi oleh wilayah seperti perbedaan negara, dsb. Namun, pemanfaatan internet tidak serta merta menjadikan penjual menghentikan komunikasi pemasaran secara tradisional, karena kolaborasi antara komunikasi pemasaran tradisional dan komunikasi pemasaran modern (internet) akan menjadikan produk lebih banyak dikenal konsumen. Melalui jaringan dunia maya (internet), komunikasi antara penjual dan konsumen akan selalu terjalin dan terhubung. 


\section{Sosial Media dalam Online Marketing di Era Digital}

Salah satu fasilitas yang banyak digunakan dalam internet adalah sosial media. Sosial media merupakan suatu teknologi online yang berguna untuk berbagi pendapat, wawasan, ataupun pengalaman kepada orang lain (Honorata Ratnawati, 2015, p.104). Definisi tersebut didukung oleh Andreas Kaplan dan Michael Haenlin dalam La Moriansyah (2015, p.188) yang juga mendefinisikan sosial media sebagai suatu wadah yang memungkinkan adanya pertukaran informasi bagi pengguna melalui grup aplikasi dengan basis internet dan dibuat menggunanakan ideologi serta teknologi web 2.0. Terdapat berbagai macam bentuk sosial media yang tentunya memiliki karakteristik yang berbeda-beda, diantaranya adalah Instagram, Twitter, Facebook, Youtube, dll. Pada awalnya, sosial media hanya digunakan oleh masyarakat untuk berkomunikasi. Seiring dengan berjalannya waktu pengguna sosial media pun terus bertambah, kondisi tersebut dimanfaatkan oleh pemasar dengan memanfaatkan sosial media sebagai alat pemasaran yakni menjadikan sosial media sebagai sarana promosi. Media sosial dapat dijadikan sebagai sarana dalam berbagi informasi yang berupa teks, audio, picture atau gambar, bahkan video bagi pemasar kepada konsumennya (Kotler dan Armstrong, 2012).

Dikutip dari hasil survey We Are Sosial per-Januari 2019, dari populasi yang ada, terdapat 56\% pengguna aktif sosial media di Indonesia (Simon Kemp, 2019). Hasil tersebut dapat terlihat dari data gambar berikut:

Gambar 1. Data Pengguna Sosial Media di Indonesia per Januari 2019

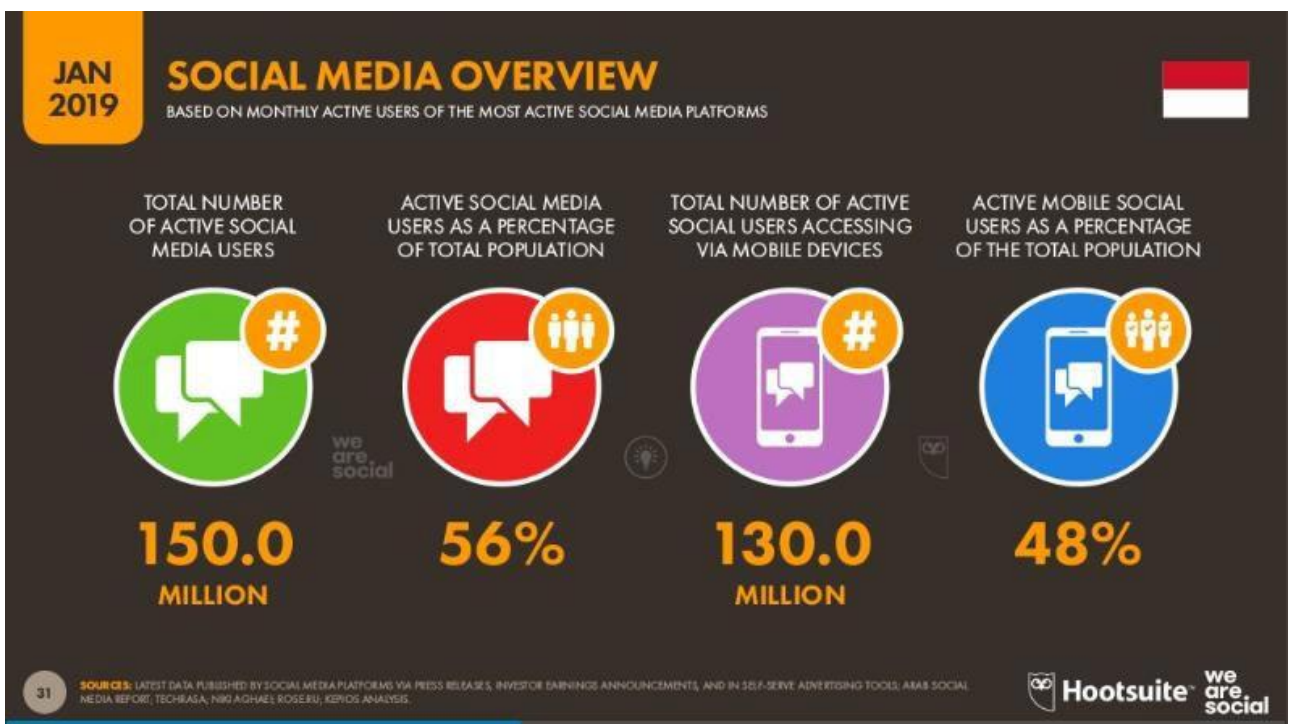

Sumber: datareportal.com

Sedangkan terkait dengan data sosial media yang tergolong dalam sosial network yang lebih sering digunakan di Indonesia per-Januari 2019 adalah Youtube dengan persentase $88 \%$, kemudian disusul oleh Facebook dengan persentase sebesar 
$81 \%$, Instagram dengan persentase sebesar $80 \%$, dan Twitter dengan persentase sebesar 52\%, yang selanjutnya juga terdapat LinkedIn, Pinterest, Snapchat, Path, dan Tumber dengan posisi berurutan kebawah, serta ReddIt dengan posisi terbawah (Simon Kemp, 2019). Berikut merupakan gambar diagram terkait data tersebut:

Gambar 2. Platform media sosial yang sering digunakan per Januari 2019

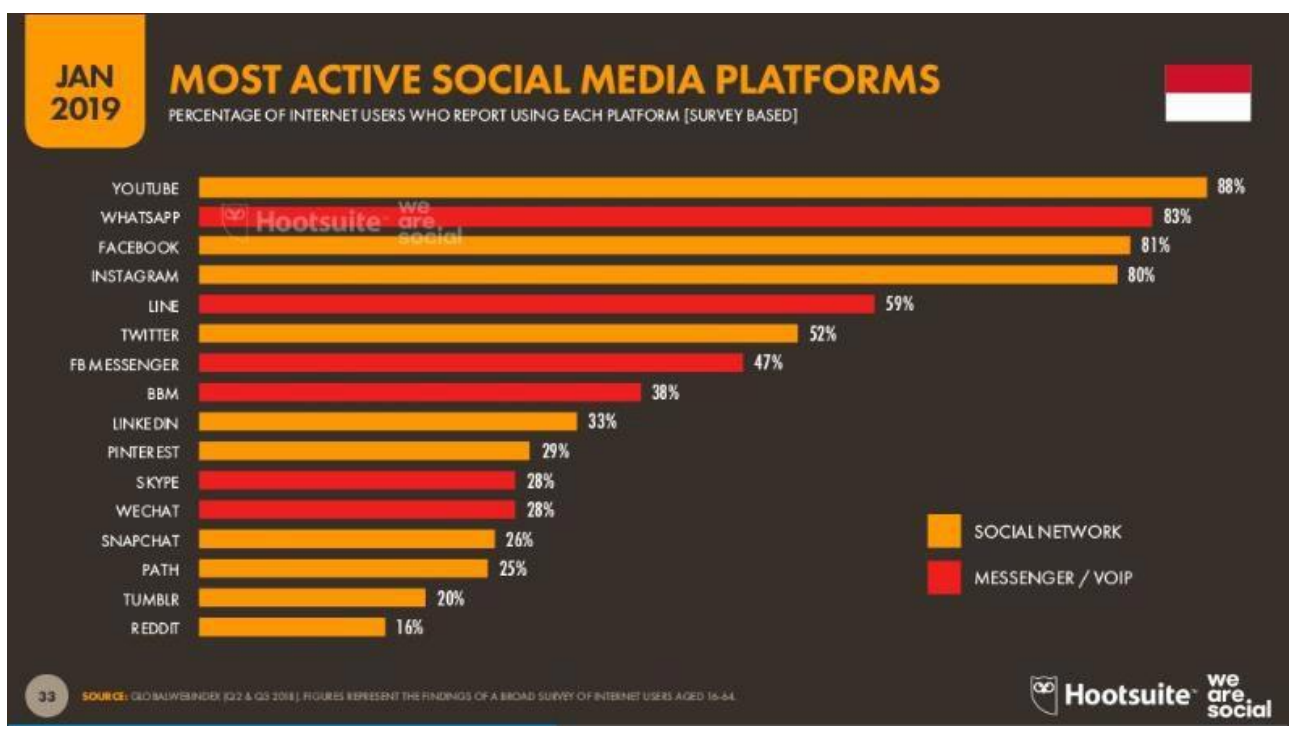

Sumber: datareportal.com

Penggunaan sosial media sebagai online marketing tentu memiliki perbedaan dibandingkan traditional marketing. Perbedaan tersebut salah satunya dapat dilihat dari target pasar, konsumen pada sosial media atau online marketing cenderung merupakan orang-orang yang melek terhadap teknologi karena dapat aktif berinteraksi dalam sosial media. Sedangkan dalam traditional marketing yang salah satu contohnya adalah melalui billboard, cenderung dapat dilihat oleh seluruh kalangan, meskipun target pasar sasaran yang dituju tidak dapat difokuskan secara personal. Penggunaan sosial media sebagai online marketing tentunya juga memiliki beberapa keunggulan, yang salah satunya adalah menayangkan iklan yang sesuai dengan kebutuhan dan selera konsumen. Dengan keunggulan tersebut, penjual akan merasa terbantu dalam menentukan segmentasi dan targeting pada pasar, aktivitas advertising (iklan) juga akan menjadi lebih efektif dan tepat sasaran. Hal tersebut juga akan meminimalisir adanya ketidaknyamanan dari pengguna sosial media karena iklan yang tayangkan akan berguna bagi pengguna dikarenakan iklan tersebut sesuai dengan kebutuhan dan selera mereka (Tucker. 2014). Baik online marketing ataupun traditional marketing pasti memiliki kelebihan dan kekurangan masingmasing. Oleh karena itu, pemasar atau penjual juga harus dapat menganalisis target pasarnya dengan baik sebelum menggunakan sosial media sebagai online marketing.

Aktivitas pemasaran dalam sosial media dapat meliputi pengunggahan 
produk yang ditawarkan, pemberian tanggapan kepada konsumen terkait produk pada saat konsumen mengajukan pertanyaan, dan melakukan advertising terkait produk di sosial media. Bahkan, terdapat beberapa pemilik bisnis yang menggunakan brand abasador dalam merekomendasikan produk yang dijual dalam sosial media. Aktivitas seperti advertising dan penggunaan brand ambassador dalam sosial media tersebut dapat menjadi batu pijakan dalam meningkatkan brand awareness suatu produk. Disamping itu, penjual yang aktif dalam menanggapi pertanyaan konsumen dengan ramah dan santun akan mendukung terciptanya citra baik penjual dan produk bagi konsumennya. Citra baik penjual dan produk yang telah terbentuk akan dapat memunculkan minat beli konsumen terhadap produk.

Apabila dikaitkan dengan pembentukan citra baik dan minat beli, tentunya kedua hal tersebut akan memiliki keterkaitan dengan komentar, tanggapan atau opini dari para konsumen terkait pengalaman pembelian produk sebelumnya. Dalam sosial media, konsumen yang telah membeli produk, secara bebas dapat membagikan pengalamannya dengan memberi komentar terkait produk, baik itu komentar positif ataupun negatif. Komunikasi yang terjadi dari kegiatan membagi pengalaman terkait produk dalam sosial media dapat disebut sebagai electronic word of mouth (eWOM).

\section{Efektivitas Electronic Word of Mouth (e-WOM) dalam Dunia Pemasaran Online di Sosial Media}

Efektivitas menurut Dunn dalam Nabila Rachmadhania (2017, p.212) diartikan sebagai kriteria dalam melakukan seleksi terhadap alternatif-alternatif yang dapat dipilih sebagai rekomendasi yang berdasar pada pertimbangan apakah alternatif yang menjadi rekomendasi tersebut dapat menghasilkan akibat yang maksimal. Sedangkan menurut Patimeh dalam Teguh Suripto (2018, p.124), efektitivas adalah ukuran berapa jauh target yang telah ditetapkan yang dapat berupa kuantitas, kualitas, serta waktu yang dapat dicapai oleh manajemen. Apabila dikaitkan dengan Electronic Word of Mouth (e-WOM), efektivitas e-WOM dapat diartikan sebagai pengukuran untuk mengetahui seberapa besar hasil yang diperoleh dari adanya e-WOM itu sendiri.

Electronic Word of Mouth atau e-WOM merupakan suatu perkembangan dari Word of Mouth atau WOM. Esensi dari WOM dan e-WOM masih sama, yakni berbentuk suatu tanggapan, ulasan, atau opini terkait suatu produk yang disebar dari mulut ke mulut, perbedaannya hanya terletak pada e-WOM yang pelaksanaannya menggunakan media elektronik. Namun, menurut penelitian yang dilakukan oleh Lavenia Hariono (2018, p.20), menyebutkan bahwa e-WOM dapat lebih unggul dari WOM. Hal tersebut disebabkan salah satunya oleh dampak dari perkembangan teknologi yang membuat jangkauan e-WOM menjadi lebih besar dari WOM. Jangkauan yang lebih besar tersebut terbentuk karena adanya internet yang dapat menghubungkan berbagai penggunanya dimana saja dalam jumlah yang banyak dan 
tidak terbatas.

Keberhasilan kegiatan pemasaran dalam sosial media tidak dapat terlepas dari peran Electronic Word of Mouth (e-WOM). Melihat fenomena bahwa calon pembeli menjadi semakin selektif karena banyaknya pilihan produk, maka calon pembeli akan cenderung lebih percaya pada ulasan yang diberikan oleh konsumen yang memiliki pengalaman pembelian terhadap produk dibandingkan dengan iklan. Hal tersebut dapat menunjukkan bahwa pengalaman dari pembelian konsumen sebelumnya akan memiliki pengaruh dalam minat pembelian produk calon pembeli. Selanjutnya, setelah melakukan pembelian, konsumen yang merasa puas pada produk akan memberikan rekomendasi pada orang lain, terutama orang-orang yang ada di sekitarnya. Lingkaran tersebut yang disebut sebagai e-WOM, dan secara langsung juga dapat dikatakan sebagai kegiatan promosi dengan cara berbagi kegiatan pengalaman terkait produk.

Efektivitas dari e-WOM dalam dunia pemasaran online terutama sosial media dapat dilihat dari beberapa penelitian, salah satunya yakni penelitian yang dilakukan oleh Honorata Ratnawati dan Denny Pradana tentang e-WOM, kepuasan konsumen, serta pengaruhnya baik itu secara langsung ataupun tidak langsung pada minat beli konsumen. Hasil penelitian tersebut menyampaikan bahwa dengan menggunakan sosial media sebagai variabel intervening, e-WOM memiliki pengaruh terhadap minat beli konsumen. Secara lebih lanjut, responden yang merupakan mahasiswa dan pengguna aktif sosial media menyampaikan bahwa dalam sosial media, pengguna yang memiliki perilaku, selera, ataupun kebutuhan yang sama akan produk dapat membentuk suatu grup agar dapat saling bertukar informasi terkait produk, baik itu terkait dengan jenis produk ataupun harga dari produk tersebut (Honorata R. D. P., 2015, p.111).

Sedangkan menurut penelitian yang dilakukan oleh Firman Dwi Cahyono, dkk, menyebutkan bahwa dalam pelaksanaannya di sosial media Instagram, electronic word of mouth (e-WOM) dapat terbentuk dari beberapa faktor, diantaranya yaitu platform assistance atau penyedia bantuan, expressing positive feelings atau mengekspresikan perasaan/pengalaman positif, economic incentives atau penghargaan ekonomi, helping the company atau membantu perusahaan, dan concern for others atau perhatian pada orang lain (konsumen lain). Dari faktor-faktor tersebut, e-WOM dapat menjadi suatu sumber informasi bagi konsumen yang lain, informasi yang diberikan melalui e-WOM pun cenderung bersifat jujur karena berdasar pada pengalaman masing-masing individu. Hasil penelitian tersebut juga menunjukkan bahwa faktor faktor yang membentuk e-WOM tersebut dapat mempengaruhi minat beli konsumen di Instagram, terutama faktor concern for others yang memiliki pengaruh paling dominan (Firman Dwi Cahyono, dkk, 2016, p.156).

Hasil dari penelitian yang dilakukan oleh Firman dkk tersebut sejalan dengan hasil penelitian Gevi Tonida Resky (2015, p.11) yang sama-sama meneliti pengaruh dari electronic word of mouth (e-WOM) terhadap minat beli konsumen di sosial media Instagram. Hasil dari penelitian tersebut menyebutkan bahwa e-WOM dapat 
berpengaruh secara positif dan signifikan terhadap minat beli konsumen. Peneliti juga menambahkan bahwa apabila penerimaan e-WOM dalam sosial media instagram semakin banyak, maka pengaruh dari e-WOM terhadap minat beli konsumen juga semakin meningkat (lebih besar). Dari beberapa penelitian tersebut, maka dapat disimpulkan bahwa electronic word of mouth (e-WOM) dapat meningkatkan minat beli konsumen di sosial media.

\section{Minat Beli Konsumen terhadap Produk}

Minat beli merupakan tahapan pada saat konsumen menyusun pilihan diantara beberapa pilihan merek, yang selanjutnya pada akhirnya memutuskan untuk melakukan pembelian pada satu pilihan atau alternatif yang paling disenangi. Minat beli juga dapat diartikan sebagai proses yang dilewati konsumen dalam melakukan pembelian suatu produk (dapat berupa barang ataupun jasa) yang berdasar pada berbagai macam pertimbangan (Pramono, 2012, p.136). Adapun definisi dari minat beli menurut Rizky dan Yasin (2014) yaitu suatu keinginan tersembunyi yang ada pada benak atau pikiran konsumen. Minat beli konsumen terhadap produk atau merek dapat timbul apabila konsumen telah memiliki informasi terkait sikap positif pada produk atau merek tersebut (Nulufi dan Murwatiningsih, 2015).

Dari beberapa definisi tersebut, dapat terlihat bahwa minat beli konsumen pada produk akan muncul pada saat konsumen memperoleh cukup informasi terkait produk yang ingin dibeli. Dengan kata lain, informasi terkait produk menjadi kunci utama dalam menumbuhkan minat beli pada konsumen. Hal tersebut didukung oleh saran yang dikemukakan dalam penelitian Rifki dan Farida bahwa para penjual di sosial media harus memberikan informasi secara lengkap, mengupdate informasi produk secara rutin, dan terus menjaga kepercayaan konsumennya (Rifki W.N dan Farida I, 2017, p.8).

Disamping itu, Samuel dan Wijaya dalam Yuli Priyanti, dkk (2017, p.90) mengemukakan unsur-unsur yang dapat menumbuhkan minat beli seseorang, yakni:

1. Rangsangan, merupakan dorongan dalam melakukan tindakan atau suatu syarat yang membuat seseorang melakukan sesuatu.

2. Kesadaran, merupakan suatu hal yang dapat masuk dalam benak seseorang yang umumnya dipengaruhi oleh produk (dapat berupa barang atau jasa).

3. Pencarian informasi, merupakan proses mencari informasi baik itu informasi internal (data pribadi konsumen dalam memilih produk) ataupun informasi eksternal (data yang diperoleh melalui sumber sosial ataupun iklan).

Salah satu unsur minat beli yang berasal dari eksternal seorang konsumen adalah informasi. Kebutuhan konsumen akan informasi produk di sosial media tersebut akan sangat berkaitan dengan electronic word of mouth (e-WOM). Sebelum konsumen melakukan pembelian secara online, konsumen akan melakukan pencarian review produk terlebih dahulu dengan membaca ulasan, tanggapan, ataupun opini terkait pengalaman pembelian produk, dimana ulasan tersebut merupakan bentuk dari komunikasi dalam e-WOM. Mahendrayasa (2014) juga menambahkan bahwa 
komunikasi dari word of mouth memiliki pengaruh yang besar terhadap minat beli bagi konsumen yang memiliki ketertarikan dengan saran ataupun ulasan dari orang yang memiliki pengalaman pembelian produk sebelumnya.

\section{KESIMPULAN DAN SARAN}

\section{Kesimpulan}

Pemasaran bukan hanya diartikan sebagai sebatas kegiatan dalam mempromosikan suatu produk, namun juga terdiri dari berbagai rangkaian mulai dari perencanaan hingga pendistribusian produk. Perkembangan teknologi saat ini membuat kita berada pada kondisi dimana penggunaan internet telah merambah pada bidang operasi bisnis, yakni dalam kegiatan pemasaran. Internet telah dijadikan sebagai alat komunikasi pemasaran antara penjual dan konsumennya. Salah satu fasilitas yang banyak digunakan dalam internet adalah sosial media. Dalam sosial media, keberhasilan kegiatan pemasaran tidak dapat terlepas dari peran Electronic Word of Mouth (e-WOM). Secara keseluruhan, hasil kajian literatur ini dapat disimpulkan bahwa electronic word of mouth (e-WOM) dapat meningkatkan minat beli konsumen di sosial media. Hasil tersebut didukung oleh beberapa penelitian yang menunjukkan pengaruh e-WOM terhadap minat beli konsumen di sosial media. Adanya pengaruh tersebut terutama disebabkan oleh salah satu unsur dari minat beli yang berasal dari eksternal seorang konsumen yakni informasi. Sedangkan kebutuhan akan informasi bagi konsumen tersebut dapat terpenuhi dengan adanya electronic word of mouth (e-WOM).

Disamping itu, kajian literatur ini juga memiliki keterbatasan yakni karena data yang digunakan merupakan hasil dari studi literatur, sehingga terdapat kemungkinan akan adanya faktor lain yang berhubungan dengan electronic word of mouth (e-WOM) namun tidak dibahas pada penelitian ini. Selain itu, penggunaan literatur dalam penelitian ini juga masih terbatas, sehingga hal tersebut juga dapat menjadi suatu keterbatasan.

\section{Saran}

Adapun terdapat saran bagi penelitian selanjutnya yang mengkaji tentang 
electronic word of mouth (e-WOM) yakni penulis berharap agar penelitian selanjutnya dapat melakukan kajian pada lebih banyak sumber ataupun referensi yang terkait dengan efektivitas electronic word of mouth (e-WOM). Hal tersebut bertujuan agar penelitian selanjutnya menjadi lebih baik dan lengkap.

Selain itu kajian e-WOM tidak hanya terpaku pada nilai positif yang muncul dalam kegiatan pemasaran suatu produk. Peneliti kedepan perlu menggali juga efektifitas nilai negative terhadap minat beli konsumen di media sosial. Sehingga eWOM tidak hanya dimaknai sebagai sebuah penilaian mutlak yang tidak dapat diperdebatkan tetapi ada 2 sisi e-WOM yang saling berkesinambungan antara positif dan negatif yang mana nantinya akan membentuk ekosistem pasar yang sebenarnya. Penggambarang secara adil ini dapat lebih meningkatkan kredibelitas penelitian terhadap nilai dari e-WOM.

\section{DAFTAR PUSTAKA}

\section{BUKU}

Arikunto, S. (2010). Prosedur Penelitian Suatu Pendekatan Praktik. Jakarta: Rineka Cipta.

Kotler P. \& Armstrong, G. (2012). Prinsip-prinsip Pemasaran. Edisi 13. Jakarta: Erlangga

Kotler P. \& Keller K. L. (2012). Marketing Management, $14^{\text {th }}$ Edition. New Jersey: Prentice-Hall Published.

Kotler P. \& Keller K. L. (2016). Marketing Management, $15^{\text {th }}$ Edition. New Jearsey: Pearson Pretice Hall.

Suyono, A. G. Sukmawati, S. \& Pramono. (2012). Pertimbangan Dalam Membeli Produk Barang Maupun Jasa. Jakarta: Intidayu Press.

Tjiptono, F. (2014). Pemasaran Jasa, Prinsip, Penerapan dan Penelitian. Yogyakarta: Andi Offset.

\section{JURNAL/JURNAL ONLINE}

Cahyono F. D. Kusumawati, A. \& Kumadji, S. (2016). Analisis Faktor-Faktor Pembentuk Electronic Word-Of-Mouth (EWOM) dan Pengaruhnya Terhadap Minat Beli (Survei pada Followers Akun Instagram @ saboten_shokudo). Malang: Jurnal Administrasi Bisnis (JAB) Volume 37, Nomor 1.

Farisi, M. I. (2010). Pengembangan Asesmen Diri Siswa (Student Self-Assessment) sebagai Model Penilaian dan Pengembangan Karakter. Surabaya: UTSurabaya, Konferensi Ilmiah Nasional "Asesmen dan Pembangunan Karakter Bangsa” HEPI UNESA 2012. 
Hariono, L. (2018). Apakah E-WOM (Electronic Word of Mouth) Bisa Mengalahkan WOM (Word of Mouth) Dalam Mempengaruhi Penjualan Produk Kuliner. Kompetensi, Volume 12, Nomor 1.

Mahendrayasa, A. C. Kumadji, S. \& Abdillah, Y. (2014). Pengaruh Word of Mouth terhadap Minat Beli Serta Dampaknya pada Keputusan Pembelian. Malang: Universitas Brawijaya, Jurnal Administrasi Bisnis (JAB) Volume 12, Nomor 1.

Moriansyah, L. (2015). Pemasaran Melalui Media Sosial: Antecedents dan Consequences. Universitas Indonesia: Jurnal Penelitian Komunikasi dan Opini Publik Volume 19, Nomor 3.

Nasution, M. F. R. \&Yasin, H. (2014). Pengaruh Promosi dan Harga Terhadap Minat Beli Perumahan Obama PT. Nailah Adi Kurnia Sei Mencririm Medan. Jurnal Manajemen dan Bisnis Volume 4 Nomor 2.

Nulufi, K. \& Murwatiningsih. (2015). Minat Beli sebagai Mediasi Pengaruh Brand Image danSikap Konsumen terhadap Keputusan Pembelian Batik di Pekalongan. Semarang: Universitas Negeri Semarang, Management Analysis Journal, 4 (2).

Nurwibowo, R. W. Indriani, F. (2017). Analisis Faktor-Faktor yang Mempengaruhi Minat Beli Konsumen Terhadap Produk Fashion Online Melalui Jejaring Sosial Instagram. Semarang: Diponegoro Journal of Management Volume 6, Nomor 2.

Priansa, D. J. (2016). Pengaruh E-Wom dan Persepsi Nilai Terhadap Keputusan Konsumen Untuk Berbelanja Online di Lazada. Universitas Telkom: Ecodemica, Volume IV Nomor 1.

Priyanti, Y. \& Susanti, F. (2017). Nazaruddin Aziz. Minat Beli Konsumen Toko Sepatu Bata di Pasar Raya Padang Dilihat Dari Sikap dan Iklan. Jurnal Pundi Volume 01 Nomor 02.

Putranti, H. R. D. \& Pradana, D. (2015). Electronic Word of Mouth (E-WOM), Kepuasan Konsumen dan Pengaruh Langsung dan Tak Langsung Terhadap Minat Beli Konsumen (Studi Pada Mahasiswa Feb Untag di Semarang). Semarang: Media Ekonomi dan Manajemen Volume 30, Nomor 1.

Resky, G. T. (2015). Analisis Pengaruh Electronic Word of Mouth (eWom) Terhadap Minat Beli Konsumen pada Produk Tas di Instagram RGF Fashion Store. Fakultas Ekonomi dan Bisnis Universitas Brawijaya Malang.

Suripto, T. (2018). Kajian Literatur Efektifitas Pemasaran Produk dengan Menggunakan Sistim Online Marketing di Era Disruption. Yogyakarta: Universitas Alma Ata, Jurnal Ekonomi Syariah Indonesia Volume VIII, 
Nomor 2.

Tucker, C. E. (2013). Sosial Network Personalized Ad, Privacy Contro. Journal of Marketing Research.

Wilopo, N. R. \& Pangestuti, E. (2017). Pengaruh Efektivitas Iklan Online Terhadap Minat Berkunjung Serta Dampaknya Pada Keputusan Berkunjung Wisatawan Mancanegara ke DKI Jakarta. Malang: Universitas Brawijaya, Jurnal Administrasi Bisnis (JAB), Volume 46, Nomor 1.

Yulianton, H. Sutanto, F. A. \& Hadiono, K. (2017). Analisa Electronic Word of Mouth (E-WOM) Pada Media Sosial Twitter. Jurnal DINAMIK Volume 22 , Nomor 1.

\section{ARTIKEL/BERITA}

APJII (Asosiasi Penyelenggara Jasa Internet Indonesia). Profil Penggguna Internet di Indonesia Tahun 2016. (Diakses dari https://apjii.or.id pada $16 \mathrm{Mei}$ 2019).

BPS (Badan Pusat Statistik). Statistic E-Commerce 2019. (Diakses dari https://www.bps.go.id/publication/2019/12/18/fd1e96b05342e479a839 17c6/statistik-e-commerce-2019.html pada 16 Mei 2019).

Kemp, S. (2019). Digital 2019: Indonesia. (Diakses dari https://datareportal.com/reports/digital-2019-indonesia pada 18 Mei 2019). 